\title{
PENERAPAN MODEL PEMBELAJARAN INQUIRY-BASED TEACHING UNTUK MENINGKATKAN HASIL BELAJAR BAHASA INGGRIS
}

\author{
Ni Ketut Merta
}

SMK Negeri 1 Seririt

email : mertardika567@gmail.com

\begin{abstract}
Abstrak
Penelitian Tujuan penelitian ini adalah untuk meningkatkan hasil belajar bahasa inggris pada siswa kelas X Akuntansi 2 SMKN 2 Seririt pada semester ganjil tahun pelajaran 2018/2019. Penelitian ini menggunakan metode pembelajaran inquiry based teaching dengan melalui dua tahapan siklus pelaksanaan yang dimana pada setiap siklus terdiri dari perencanaan, pelaksanaan, observasi dan evaluasi. Subyek penelitian adalah siswa kelas X Akuntansi 2 yang berjumlah 35 orang. Teknik pengumpulan data yang dilakukan adalah dengan memberikan tes kepada siswa tentang teks deskripsi dan ungkapan. Data yang telah dikumpul kemudian di olah dengan metode analisis deskriptif. Hasil dari penelitian ini adalah hasil belajar yang dicapai siswa dari pra siklus yaitu sebesar $56 \%$ ke siklus I sebesar $66 \%$ yang mengalami peningkatan sebesar $15,50 \%$ serta dari siklus I sebesar $66 \%$ ke siklus II sebesar $80 \%$. Jadi dari siklus I ke siklus II terjadi rata-rata peningkatan skor sebesar $17,50 \%$ yang membuktikan bahwa metode pembelajaran yang diterapkan berhasil dalam meningkatkan hasil belajar siswa.
\end{abstract}

Kata kunci: inquiry based teaching, peningkatan hasil belajar, bahasa inggris

\begin{abstract}
The purpose of this study was to improve the learning outcomes of English in Accounting $X$ grade 2 students of SMK 2 Seririt in the odd semester of the academic year 2018/2019. This study uses the inquiry based teaching learning method through two stages of the implementation cycle which in each cycle consists of planning, implementation, observation and evaluation. The research subjects were 35 students in class X Accounting 2, which amounted to 35 people. The technique of data collection was done by giving a test to students about the description and expression texts. Data that has been collected is then processed using descriptive analysis method. The results of this study are the learning outcomes achieved by students from the pre cycle that is equal to $56 \%$ to the first cycle of $66 \%$ which has increased by $15.50 \%$ and from the first cycle of $66 \%$ to the second cycle of $80 \%$. So from the first cycle to the second cycle there was an average score increase of $17.50 \%$ which proved that the learning method applied was successful in improving student learning outcomes.
\end{abstract}

Keywords: inquiry based teaching, improving learning outcomes, English 


\section{Pendahuluan}

Pendidikan merupakan suatu proses yang diperlukan untuk mendapatkan keseimbangan dan kesempurnaan dalam perkembangan individu maupun masyarakat. Penekanan pendidikan dibanding dengan pengajaran terletak pada pembentukan kesadaran dan kepribadian individu atau masyarakat di samping transfer ilmu dan keahlian. Dengan proses semacam ini suatu bangsa atau negara dapat mewariskan nilai-nilai keagamaan, kebudayaan, pemikiran dan keahlian kepada generasi berikutnya, sehingga mereka betul-betul siap menyongsong masa depan kehidupan bangsa dan negara yang lebih cerah (Nurkholis, 2013).

Pendidikan juga merupakan kegiatan yang kompleks, dan meliputi berbagai komponen yang berkaitan erat satu sama lain. Oleh sebab itu, apabila pendidikan ingin dilaksanakan secara terencana dan teratur, maka berbagai faktor yang terlibat dalam pendidikan harus dipahami terlebih dahulu. Berbagai komponen dalam sistem pendidikan, baik secara mikro maupun dalam kajian makro perlu dikenali secara mendalam sehingga komponen-komponen tersebut dapat difungsikan dan dikembangkan guna mengoptimalkan garapan pendidikan tersebut ke arah pencapaian tujuan pendidikan yang ditetapkan (Dinn Wahyudi dkk, 2006) Pendidikan nilai merupakan (Sutrisno, 2016).

Pasal 1 UU SISDIKNAS no. 20 tahun 2003 disebutkan bahwa Sistem Pendidikan Nasional adalah keseluruhan komponen pendidikan yang saling terkait secara terpadu untuk mencapai tujuan pendidikan nasional. Berangkat dari bunyi pasal ini dapat diketahui bahwa pendidikan adalah sistem yang merupakan suatu totalitas struktur yang terdiri dari komponen yang saling terkait dan secara bersama menuju kepada tercapainya tujuan (Soetarno, 2003: 2). Adapun komponen-komponen dalam pendidikan nasional antara lain adalah lingkungan, sarana-prasarana, sumberdaya, dan masyarakat. Komponen-komponen tersebut bekerja secara bersama-sama, saling terkait dan mendukung dalam mencapai tujuan pendidikan (Munirah, 2015).

Bahasa inggris merupakan salah satu mata pelajaran penting di Sekolah Menengah Atas/Kejuruan. Bahasa inggirs dBahasa Inggrisndang penting mengingat bahasa inggris merupakan bahasa universal yang dapat digunakan untuk menjalin komunikasi di berbagai belahan Dunia. Mengingat begitu pentingnya mata pelajaran bahasa inggris, menjadikan pelajaran bahasa inggris diberikan sejak dini bahkan beberapa ada yang sudah memberikannya sejak taman kanak-kanak hingga Sekolah Menengah Atas/Kejuruan.

Kelas X Sekolah Menengah Kejuruan merupakan jenjang awal pendidikan menengah atas dimana merupakan masa-masa adaptasi dari Sekolah Menengah Pertama yang mungkin bagi beberapa siswa memerlukan waktu pada masa peralihan tersebut. Dalam penerapannya tentu ada sedikit tambahan beban proses belajar mengajar terutama pada pelajaran bahasa inggris karena tentunya setiap siswa memiliki kemampuan yang berbeda-beda dalam pemahaman bahasa inggris, di sisi lain tentunya ada beberapa siswa yang mungkin menjadikan pelajaran bahasa inggris sebagai pelajaran yang bukan favoritnya sehingga mengikuti proses belajar seadanya. Untuk memenuhi KKM dan juga meningkatkan motivasi belajar siswa dalam pelajaran bahasa inggris tentunya diperlukan strategi pembelajaran khusus yang tepat dalam proses penyampaian materi terhadap siswa.

Beberapa teori untuk menjawab masalah tersebut yang menawarkan model-model pembelajaran yang dapat diterapkan tentunya sudah ada begitu banyak, namun tidak semuanya dapat diterapkan pada kondisi obyek yang berbeda. Di SMKN 2 Seririt beberapa siswa kelas $X$ akuntansi 2 yang dimana dijadikan sebagai subjek penelitian, beberapa siswanya belum mampu untuk melafalkan dan juga menuliskan grammar bahasa inggris yang baik sehingga belum mampu untuk mencapai KKM, namun di sisi lain ada pula siswa yang telah mampu untuk melafal dan menuliskan grammar nya dengan baik namun masih perlu pengembangan lebih lanjut lagi.

Dengan kendala-kendala tersebut, penulis memilih metode pembelajaran inquiry-based teaching yang dimana melalui metode pembelajaran ini memberikan kesempatan kepada siswa untuk secara intensif mengajukan pertanyaan atau permasalahan, mengajukan hipotesis, 
melakukan observasi atau investigasi, menganalisis data, dan menarik simpulan, serta menjelaskan temuannya itu kepada orang lain. Sehingga menjadikan siswa dapat bereksplorasi mendeskripsikan sesuatu hal yang pernah langsung di alami atau hal yang telah di observasi sebelumnya dan menterjemahkannya ke dalam bahasa inggris.

Penerapan metode pembelajaran inquiry-based teaching diharapkan dapat mengakomodasi seluruh siswa untuk memiliki pemahaman yang sama tentang pembelajaran bahasa inggris, memiliki kemauan untuk mencoba mengeksplorasi diri dalam menulis dan berbicara dalam bahasa inggris sehingga seluruh siswa merata mencapai KKM yang telah ditentukan. Berdasarkan latar belakang tersebut penelitian bertujuan untuk meningkatkan hasil belajar bahasa inggris pada siswa kelas $X$ akuntansi 2 di SMKN 2 Seririt dengan menerapkan metode inquiry-based teaching.

\section{Metode}

Penelitian ini menggunakan jenis penelitian tindakan kelas yang siklus penelitiannya berdasarkan pada konsep penelitian yang dikembangkan oleh Kemmis dan Mcc. Thargat, dimana setiap siklus terdirir dari perencanaan, pelaksanaan, pengamatan dan refleksi. Penelitian ini dilaksanakan di Sekolah Menengah Kejuruan Negeri 2 Kelas X Akuntansi 2 Kecamatan Seririt Kabupaten Buleleng pada Semester Ganjil Tahun Pelajaran 2018/2019 yang akan dilaksanakan selama 4 Bulan rentang Agustus sampai dengan Oktober 2018. Subyek dalam penelitian ini adalah siswa kelas kelas X Akuntansi 2 SMK Negeri 2 Seririt pada semester ganjil tahun ajaran 2018/2019 yang berjumlah 36 orang siswa. Obyek dari penelitian ini adalah hasil belajar siswa dalam mata pelajaran bahasa inggris dengan penerapan dari metode pembelajaran inquiry based teaching. Dalam penelitian tindakan kelas dilaksanakan dua tahap siklus penelitian, tiap siklus terdiri dari empat tahapan sebagai berikut : Perencanaan, Tindakan, Observasi, Refleksi.

\section{Hasil Dan Pembahasan}

Hasil Penelitian Penelitian Siklus I

\section{a. Perencanaan}

Tahap perencanaan ini disusun berdasarkan refleksi awal yang telah dilakukan. Adapun beberapa hal yang direncanakan yaitu (1) melakukan sosialisasi metode pembelajaran inquiry based teaching kepada siswa, (2) menyiapkan rencana pelaksanaan pembelajaran dengan menggunakan metode pembelajaran inquiry based teaching (3) menyiapkan instrumen penelitian yaitu tes evaluasi untuk siklus I serta menyusun skenario pembelajaran dengan menggunakan metode pembelajaran inquiry based teaching. Siklus satu direncanakan dalam 3 kali pertemuan yaitu dua kali pembelajaran dan satu kali evaluasi.

\section{b. Pelaksanaan}

Pelaksanaan penelitian siklus I dilaksanakan dalam tiga kali pertemuan yang dijabarkan sebagai berikut :

Pertemuan I dilaksanakan pada tanggal 12 Februari 2018, materi yang dibahas sesuai dengan RPP 1 (terlampir) yaitu tentang teks deskripsi yang dimana nantinya siswa akan diberikan contoh sebuah teks deskripsi yang kemudian akan dijadikan sebagai acuan atau contoh pembuatan teks deskripsi oleh siswa. Pertama tama guru akan memberikan penjelasan tentang sistematika teks deskripsi dan setelah penjelasan guru akan memberikan kesempatan siswa untuk bertanya terkait dengan sistematika teks deskripsi yang telah dijelaskan. Setelah itu guru akan meminta siswa untuk membuat teks deskripsi dengan pertama-tama melakukan investigasi melalui observasi atau wawancara untuk mendapatkan data sesuai dengan teks deskripsi yang akan dibuat dan membawa hasil investigasi nya tersebut pada pertemuan berikutnya.

Pertemuan kedua dilaksanakan pada tanggal 19 Februari 2018. Pada pertemuan ke dua dengan data hasil investigasi yang telah di bawa siswa, guru menugaskan siswa untuk 
membuat teks deskripsi berdasarkan hasil dari investigasi yang telah dilakukan. Setelah menyelesaikan teks deskripsi, siswa akan diminta untuk memaparkan teks deskripsinya di hadapan teman-temannya dan membuka sesi tanya jawab dalam bahasa inggris mengenai teks deskripsi yang telah dibuat. Setelah adanya pemaparan dari siswa dan tanya jawab yang dilakukan, siswa dapat melakukan refleksi terhadap teks deskripsi yang dibuatnya untuk menambahkan atau mengurangi hal-hal di dalam teks deskripsinya agar menjadi sebuah teks deskripsi yang lebih sempurna.

Setelah semua murid selesai memparkan teks deskripsinya, guru akan memilih teks deskripsi terbaik yang akan digunakan sebagai teks deskripsi dalam tes yang akan diberikan kepada seluruh siswa kelas X Akuntansi 2 SMKN 2 Seririt.

Pertemuan ketiga dilaksanakan pada tanggal 26 Februari 2018. Pada pertemuan ini, guru mengulang sekilas materi ajar yang telah diberikan pada pertemuan pertama dan kedua dengan tujuan agar siswa dapat mengingat materi yang telah dipelajari. Selanjutnya, siswa akan diuji kemampuan dan pemahamannya tentang materi yang telah dipelajari dengan evaluasi siklus I.

\section{c. Observasi}

Hasil observasi pada siklus I (lembar jawaban terlampir), dapat diketahui bahwa dapat terjadi peningkatan rata-rata skor sebesar $6,15 \%$ dimana siswa yang mampu mencapai ketuntasan KKM adalah 18 orang siswa dari 26 siswa. Hal ini disebabkan karena siswa belum dapat sepenuhnya menyerap materi pelajaran yang disampaikan oleh Guru. Siswa yang belum mencapai KKM masih kurang serius dalam mengikuti pelajaran. Hasil rata-rata skor dikonversikan dalam PAP sebagai berikut termasuk dalam kategori sedang:

Tabel 1. Pedoman Konversi PAP Skala Lima Tentang Data Hasil Belajar

\begin{tabular}{cc}
\hline Persentase & Tingkat hasil belajar \\
\hline $90-100$ & Sangat tinggi \\
$80-89$ & Tinggi \\
$65-79$ & Sedang \\
$55-64$ & Rendah \\
$0-54$ & Sangat rendah \\
\hline
\end{tabular}

Tingkat ketuntasan siswa ditendtukan dengan menggunakan rumus :

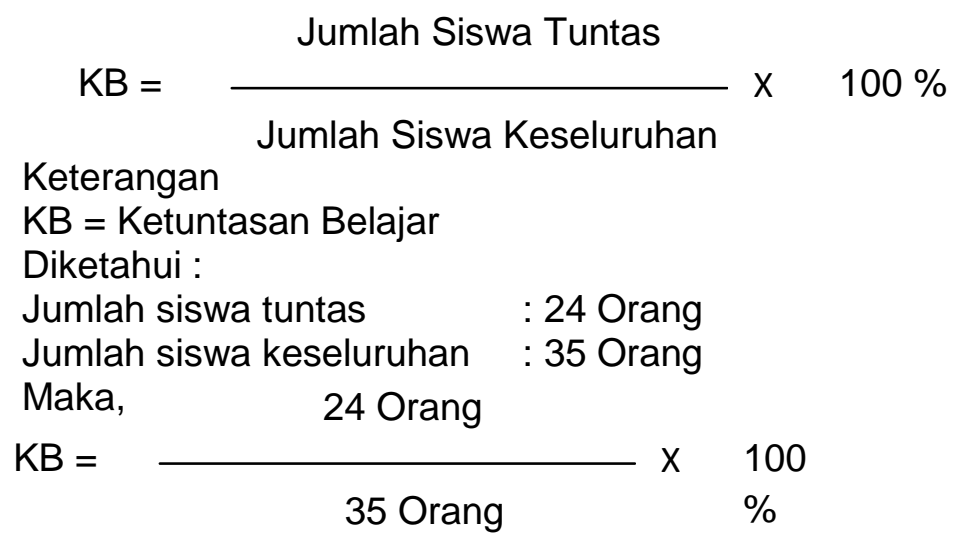

$\mathrm{KB}=68,57 \%$

Ketuntasan belajar dikonversikan ke dalam kriteria PAP skala lima seperti dalam Tabel berikut : 
Tabel 2. Pedoman Konversi PAP Skala Lima Tentang Data Hasil Belajar

\begin{tabular}{cc}
\hline Persentase & Tingkat hasil belajar \\
\hline $90-100$ & Sangat tinggi \\
$80-89$ & Tinggi \\
$65-79$ & Sedang \\
$55-64$ & Rendah \\
$0-54$ & Sangat rendah \\
\hline
\end{tabular}

Berdasarkan perhitungan di atas di dapatkan bahwa presentase ketuntasan belajar bahasa inggris kelas $\mathrm{X}$ Akuntansi 2 SMKN 2 Seririt tentang teks deskripsi pada siklus I mencapai $68,57 \%$ dan tergolong sedang. Penelitian pada siklus I belum memenuhi kriteria keberhasilan karena masih tersisa 11 siswa yang belum mencapai KKM.

d. Refleksi Siklus I

Hasil belajar pada siklus I (lembar jawaban terlampir), disajikan pada Tabel 3.

Tabel 3. Data Hasil Belajar Siklus 1

\begin{tabular}{|c|c|c|c|}
\hline No. & Nama & Nilai Pra Siklus & Nilai Siklus I \\
\hline 1 & 001 & 40 & 40 \\
\hline 2 & 002 & 70 & 70 \\
\hline 3 & 003 & 80 & 80 \\
\hline 4 & 004 & 70 & 70 \\
\hline 5 & 005 & 70 & 70 \\
\hline 6 & 006 & 70 & 70 \\
\hline 7 & 007 & 70 & 70 \\
\hline 8 & 008 & 80 & 80 \\
\hline 9 & 009 & 50 & 50 \\
\hline 10 & 010 & 40 & 40 \\
\hline 11 & 011 & 70 & 70 \\
\hline 12 & 012 & 70 & 70 \\
\hline 13 & 013 & 60 & 60 \\
\hline 14 & 014 & 70 & 70 \\
\hline 15 & 015 & 70 & 70 \\
\hline 16 & 016 & 50 & 50 \\
\hline 17 & 017 & 50 & 50 \\
\hline 18 & 018 & 70 & 70 \\
\hline 19 & 019 & 70 & 70 \\
\hline 20 & 020 & 60 & 60 \\
\hline 21 & 021 & 40 & 40 \\
\hline 22 & 022 & 50 & 50 \\
\hline 23 & 023 & 50 & 50 \\
\hline 24 & 024 & 70 & 70 \\
\hline 25 & 025 & 50 & 50 \\
\hline 26 & 026 & 90 & 90 \\
\hline 27 & 027 & 70 & 70 \\
\hline 28 & 028 & 70 & 70 \\
\hline 29 & 029 & 80 & 80 \\
\hline 30 & 030 & 70 & 70 \\
\hline 31 & 031 & 70 & 70 \\
\hline 32 & 032 & 80 & 80 \\
\hline 33 & 033 & 90 & 90 \\
\hline
\end{tabular}




\begin{tabular}{cccc}
\hline No. & Nama & Nilai Pra Siklus & Nilai Siklus I \\
\hline 34 & 034 & 70 & 70 \\
35 & 035 & 80 & 80 \\
\hline & Jumlah Skor Seluruh Siswa & 1960 & 2310 \\
& Rata-Rata Skor & 56 & 66 \\
\hline
\end{tabular}

Berdasarkan hasil analisis pada siklus I, penerapan metode pembelajaran inquiey based teaching dalam pembelajaran bahasa inggris kelas X Akuntansi 2 SMKN 2 Seririt pada semester ganjil sudah mengalami peningkatan dibandingkan tes pra siklus sebelumnya, namun belum dapat dilaksanakan secara optimal. Hal ini bisa dilihat dari belum semua mahasiswa yang dapat mencapai ketuntasan KKM yang disebabkan karena siswa kurang serius dalam mengikuti pembelajaran. Hal-hal yang dicermati dan diperhatikan pada penggunaan metode pembelajaran inquiry based teaching yang telah dilaksanakan adalah mengenai proses pembelajaran yang berdampak pada hasil belajar.

Setelah melakukan refleksi terhadap pelaksaan tindakan siklus I, ada beberapa hal yang ditemukan terkait dengan proses penilaian dan pembelajaran secara umum adalah siswa belum terbiasa dengan metode pembelajaran yang diterapkan, sehingga proses pembelajaran belum terlaksana secara optimal. Hal ini terjadi karena metode ini merupakan hal baru bagi siswa yang berbeda dengan proses pembelajaran sebelumnya yang dilaksanakan di kelas, siswa masih kurang serius dalam memahami teks deskripsi dan juga melakukan investigasi sehingga masih ditemukan beberapa teks deskripsi yang merupakan bagian dari perkiraan semata. Dari faktor lain, guru juga belum mampu menerapkan dengan baik metode pembelajaran inquiry based teaching dalam pembelajaran. Akibatnya penerapan metode pembelajaran kooperatif Inquiry Based Teaching dalam pembelajaran bahasa inggris pada kelas $X$ Akuntansi 2 SMKN 2 Seririt belum memenuhi kriteria keberhasilan. Oleh karena itu perlu diatur ulang untuk mencapai hasil yang di inginkan.

Berdasarkan refleksi di atas, peneliti memutuskan untuk melaksanakan siklus berikutnya untuk dapat memenuhi keberhasilan sesuai dengan yang di inginkan. Adapun beberapa tindakan yang diubah atau ditambah pada pelaksanaan siklus berikutnya meliputi (1) memberikan contoh yang lebih nyata dalam penjelasan terkait dengan materi pembelajaran yang diberikan (2) peneliti menjelaskan pada siswa secara jelas mengenai langkah-langkah pembelajaran dengan metode pembelajaran inquiry based teaching

Hasil Penelitian Siklus II

\section{a. Perencanaan}

Berdasarkan hasil refleksi pada siklus I, maka dapat dirancang langkah-langkah pelaksanaan tindakan sebagai berikut : 1) Menyiapkan rencana pelaksanaan pembelajaran dengan menggunakan metode pembelajaran inquiry based teaching yang disesuaikan dengan langkah-langkah pembelajaran yang ada dalam metode pembelajaran inquiry based teaching, 2) Menyiapkan materi yang akan disampaikan kepada siswa, 3) Menyusun skenario pembelajaran yang sesuai dengan langkah-langkah metode pembelajaran inquiry based teaching, 4) Menyiapkan tes evaluasi siklus I

\section{b. Pelaksanaan Penelitian}

Siklus II ini terdiri dari 3 pertemuan, dimana pada pertemuan pertama dan kedua melakukan proses pembelajaran dan pertemuan ketiga melakukan evaluasi pembelajaran yang dijabarkan sebagai berikut :

Pertemuan I dilaksanakan pada tanggal 5 Maret 2018, materi yang dibahas sesuai dengan RPP 2 (terlampir) yaitu tentang ungkapan pemberian selamat dan pujian. Pembelajaran dilaksanakan menurut metode pembelajaran inquiry based teaching.

Pada tahap berikutnya siswa akan diberikan sebuah teks dialog yang didalamnya terdapat dialog pemberian selamat dan pujian serta respon yang diberikan. Guru akan menjelaskan tentang ungkapan pemberian selamat dan pujian dan juga respon lazim yang 
diberikan dalam dialog. Setelah Guru menjelaskan, masing-masing siswa yang telah dBahasa Inggrissang-pasangkan diminta untuk memberikan contoh dialog secara verbal di depan kelas.

Selanjutnya guru akan membuka sesi tanya jawab tentang ungkapan pemberian selamat dan pujian serta pemberian responnya kepada siswa agar siswa dapat lebih memahami secara mendalam tentang ungkapan pemberian selamat dan pujian. Setelah semua siswa memahami tentang ungkapan pemberian selamat dan pujian serta responnya, maka siswa akan diminta untuk memilih kelompok teman sebangku sebagai teman dialog. Guru kemudian meminta siswa untuk melakukan investigasi terkait dengan latar dialog yang sesuai dengan dialog pemberian ucapan selamat dan pujian agar konteks dialognya sesuai dengan latar yang akan dibuat dan ditampilkan.

Pertemuan kedua dilaksanakan pada tanggal 12 Maret 2018. Pada pertemuan ini, siswa yang telah siap dengan ide latar dialog yang telah ditugaskan sebelumnya, mulai menyusun teks dialog pemberian ucapan selamat dan pujian bersama teman sebangkunya. Siswa yang telah selesai membuat teks dialog akan diminta untuk mendemonstrasikan dialognya di depan kelas dan disaksikan teman lainnya yang nantinya teman lainnya akan diberikan kesempatan untuk melakukan komentar terhadap dialog yang di tampilkan.

Guru selanjutnya akan melakukan pemilihan tehadap teks dialog yang terbaik untuk nantinya dijadikan soal dalam evaluasi yang dilakukan dan memberikan penghargaan kepada kelompok siswa dengan teks dialog dan latar terbaik.

Pertemuan ketiga dilaksanakan pada tanggal 19 Maret 2018. Pada pertemuan ini, guru mengulang sekilas materi ajar yang telah diberikan pada pertemuan pertama dan kedua dengan tujuan agar siswa dapat mengingat materi yang telah dipelajari. Selanjutnya, siswa akan diuji kemampuan dan pemahamannya tentang materi yang telah dipelajari dengan evaluasi siklus II.

\section{c. Observasi}

Hasil belajar pada siklus II sudah mengalami peningkatan, terbukti dengan 32 siswa sudah mampu mencapai KKM. Setelah dilakukan perbaikan terhadap pembelajaran pada siklus II dapat diperoleh hasil 32 siswa mampu mendapatkan nilai di atas KKM. Pada siklus II siswa sudah mulai serius belajar dan mampu berinteraksi dengan baik sehingga penerapan metode pembelajaran inquiry based teaching sudah optimal. Rata-rata skor dikonversikan ke dalam PAP skala lima masuk dalam kategori sedang.

Hasil rata-rata skor dikonversikan dalam PAP sebagai berikut termasuk dalam kategori sedang:

Tabel 4. Pedoman Konversi PAP Skala Lima Tentang Data Hasil Belajar

\begin{tabular}{cc}
\hline Persentase & Tingkat hasil belajar \\
\hline $90-100$ & Sangat tinggi \\
$80-89$ & Tinggi \\
$65-79$ & Sedang \\
$55-64$ & Rendah \\
$0-54$ & Sangat rendah \\
\hline
\end{tabular}

Tingkat ketuntasan siswa ditendtukan dengan menggunakan rumus :

$$
\mathrm{KB}=\frac{\text { Jumlah Siswa Tuntas }}{\text { Jumlah Siswa Keseluruhan }} \times 100 \%
$$

Keterangan .

$\mathrm{KB}=$ Ketuntasan Belajar

Diketahui :

Jumlah siswa tuntas 
Jumlah siswa keseluruhan : 35 Orang

Maka

$\mathrm{KB}=\frac{32 \text { Orang }}{35 \text { Orang }} \times 100 \%$

$\mathrm{KB}=88,89 \%$

Ketuntasan belajar dikonversikan ke dalam kriteria PAP skala lima seperti dalam Tabel 5 masuk dalam kategori tinggi.

Tabel 5. Pedoman Konversi PAP Skala Lima Tentang Data Hasil Belajar

\begin{tabular}{cc}
\hline Persentase & Tingkat hasil belajar \\
\hline $90-100$ & Sangat tinggi \\
$80-89$ & Tinggi \\
$65-79$ & Sedang \\
$55-64$ & Rendah \\
$0-54$ & Sangat rendah \\
\hline
\end{tabular}

Berdasarkan perhitungan di atas di dapatkan bahwa presentase ketuntasan belajar bahasa inggris pada kelas X Akuntansi 2 SMKN 2 Seririt pada siklus II mencapai 88,89\% dan tergolong sangat tinggi. Hal ini menunjukkan bahwa penelitian pada siklus II sudah memenuhi kriteria keberhasilan yang ditentukan, karena pada siklus II semua siswa sudah mampu mencapai KKM.

Dengan demikian dapat disimpulkan bahwa peningkatan prestasi belajar siswa pada mata pelajaran bahasa inggris dari tes siklus I ke siklus II dengan metode pembelajaran inquiry based teaching memperlihatkan hasil yang memuaskan yaitu mengalami peningkatan dari ratarata skor pada siklus satu yaitu sebesar $66 \%$ menjadi $80 \%$ pada siklus II.

Tabel 6. Data Hasil Belajar Siklus II

\begin{tabular}{ccccc}
\hline No. & Nama & Nilai Pra Siklus & Nilai Siklus I & Nilai Siklus II \\
\hline 1 & 001 & 30 & 40 & 70 \\
2 & 002 & 50 & 70 & 80 \\
3 & 003 & 80 & 80 & 90 \\
4 & 004 & 50 & 70 & 80 \\
5 & 005 & 70 & 70 & 90 \\
6 & 006 & 40 & 70 & 80 \\
7 & 007 & 70 & 70 & 90 \\
8 & 008 & 60 & 80 & 90 \\
9 & 009 & 30 & 50 & 70 \\
10 & 010 & 30 & 40 & 80 \\
11 & 011 & 60 & 70 & 90 \\
12 & 012 & 60 & 70 & 80 \\
13 & 013 & 40 & 60 & 70 \\
14 & 014 & 60 & 70 & 90 \\
15 & 015 & 60 & 70 & 80 \\
16 & 016 & 40 & 50 & 60 \\
17 & 017 & 50 & 50 & 60 \\
18 & 018 & 60 & 70 & 90 \\
19 & 019 & 70 & 70 & 70 \\
20 & 020 & 60 & 60 & 70 \\
\hline
\end{tabular}




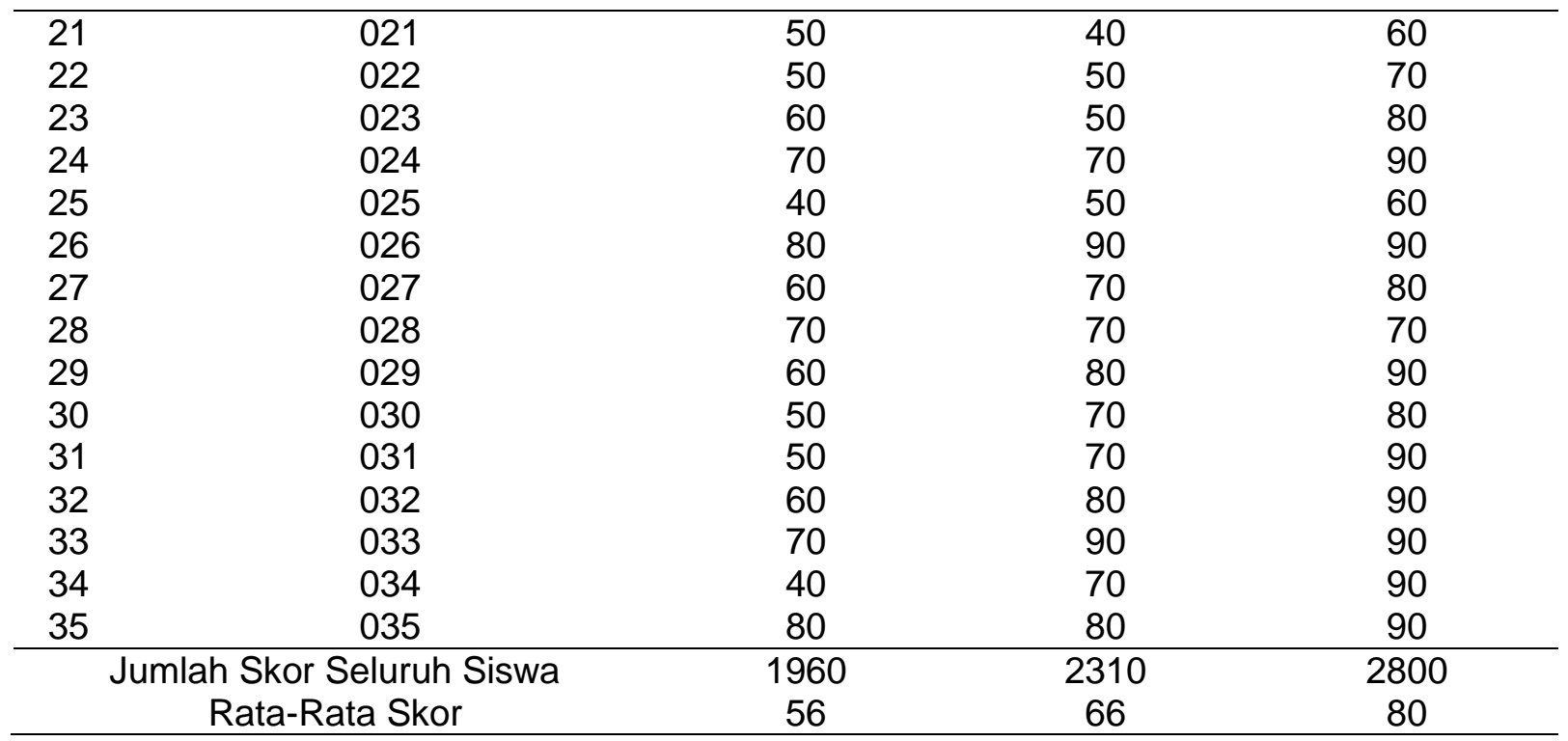

Setelah dilaksanakan tindakan dan observasi pada siklus II, masalah dan kendala yang ditemui pada siklus I dapat di atasi. Segala proses kegiatan dari perencanaan hingga pelaksanaan tindakan dan evaluasi pada siklus II sudah diperbaiki sehingga hasil yang dicapai siswa mengalami peningkatan. Hal ini terbukti dengan adanya peningkatan prestasi belajar bahasa inggris tentang teks deskripsi dan pemberian ungkapan selamat dan pujian kelas $X$ Akuntansi 2 SMKN 2 Seririt. Adapun peningkatan prestasi belajar yaitu 32 atau $91 \%$ siswa sudah mampu mencapai kriteria ketuntasan minimal (KKM) 70. Peningkatan hasil belajar bahasa inggris siswa dengan rata-rata skor (dalam persen) $66 \%$ pada siklus I dan $80 \%$ pada siklus II. Dengan presentase peningkatan prestasi belajar dari siklus I ke siklus II sebesar $17,50 \%$. Dengan tercapainya ketuntasan belajar siswa yang sudah mencapai $91 \%$, maka penelitian ini dihentikan pada siklus II.

Berdasarkan hasil analisis prestasi belajar pada siklus I dan siklus II dikemukakan bahwa hasil tentang prestasi belajar bahasa inggris siswa kelas $X$ Akuntansi 2 SMKN 2 Seririt Semester Ganjil Tahun Pelajaran 2018/2019 tentang materi teks deskripsi dan ungkapan pemberian selamat dan pujian di SMKN 2 Seririt diperoleh rata-rata skor (dalam persen) pada siklus I sebesar $66 \%$ dan pada siklus II sebesar $80 \%$.

Dengan hasil konversi PAP skala lima, presentase prestasi belajar pada penelitian tindakan kelas ini berada pada kategori sedang untuk siklus I dan masuk dalam kategori tinggi pada siklus II. Hasil penelitian tindakan kelas dari pra siklus hingga siklus II dapat dilihat pada Tabel 7.

Tabel 7. Hasil Penelitian Tindakan Kelas

\begin{tabular}{lllll}
\hline \multicolumn{1}{c}{ Tahapan } & Total Skor & Rata-Rata Skor & Kategori & Peningkatan \\
& & & & \\
\hline Pra Siklus & 1960 & 56 & Rendah & - \\
Siklus I & 2310 & 66 & Sedang & $15,50 \%$ \\
Siklus II & 2800 & 80 & Tinggi & $17,50 \%$ \\
\hline
\end{tabular}

Berdasarkan analisis terhadap hasil penelitian pada siklus I dan II di atas, peneliti menyatakan bahwa metode pembelajaran inquiry based teaching pada kelas X Akuntansi 2 SMKN 2 Seririt ini terbukti yang dilihat dari prestasi belajar bahasa inggris yang mengalami peningkatan sebesar $15,50 \%$ pada tahapan pra siklus ke siklus I dan sebanyak $17,50 \%$ dari siklus I ke siklus II. 
Metode pembelajaran inquiry based teaching adalah salah satu metode pembelajaran yang cukup mudah diterapkan karena tidak memerlukan ruangan atau perlengkapan lain secara khusus (Nurohma, 2012). Metode pembelajaran inquiry based teaching memiliki banyak manfaat, antara lain sebagai alternatif untuk menciptakan kondisi yang variatif dalam kegiatan belajar mengajar, melatih untuk dapat berpikir lebih kritis, mudah dilaksanakan pada kelas yang jumlah siswa nya banyak, membantu guru dalam menyelesaikan masalah pembelajaran seperti meningkatkan prestasi belajar siswa.

Setelah penerapan model pembelajaran menggunakan metode pembelajaran inquiry based teaching dalam pembelajaran bahasa inggris pada siswa kelas X Akuntansi 2 SMKN 2 Seririt diperoleh hasil bahwa model ini dapat meningkatkan hasil belajar siswa pada pelajaran bahasa inggris tentang teks deskripsi dan pemberian ungkapan selamat dan pujian. Hal ini terbukti dari hasil analisis data yang dapat dilihat dari peningkatan hasil belajar bahasa inggris siswa pada siklus I ke siklus II yakni sebesar $17,50 \%$ dimana perolehan nilai rata-rata presentase siklus I sebesar $66 \%$ naik menjadi $80 \%$ pada siklus II yang masuk pada kategori tinggi. Dengan kata lain, penelitian ini sudah dikatakan berhasil karena sudah memenuhi standar keberhasilan yang ditentukan oleh peneliti yaitu secara individu siswa sudah mampu mencapai kriteria ketuntasan minimal (KKM) dengan skor 70 dan dapat mencapai rata-rata nilai siswa secara keseluruhan dengan kategori tinggi.

Hasil belajar merupakan tujuan akhir yang diharapkan dalam kegiatan pembelajaran yang dilakukan oleh pendidik. Melalui penelitian dengan menerapkan metode pembelajaran inquiry based teaching hasil belajar siswa dari siklus I ke siklus II dapat ditingkatkan. Dilihat dari hasilhasil yang diperoleh, secara umum penelitian ini dapat dikatakan telah menjawab permasalahan yang telah dirumuskan.

\section{Simpulan dan Saran}

Berdasarkan hasil penelitian dan pembahasan yang telah diuraikan sebelumnya, maka dapat disimpulkan bahwa penerapan metode pembelajaran inquiry based teaching dalam pembelajaran dapat meningkatkan prestasi belajar bahasa inggris tentang teks dialog dan pemberian ungkapan ucapan selamat dan pujian kelas X Akuntansi 2 SMKN 2 Seririt. Hal ini dapat dilihat dari rata-rata hasil belajar yang dicapai siswa dari pra siklus yaitu sebesar $56 \%$ ke siklus I sebesar $66 \%$ yang mengalami peningkatan sebesar $15,50 \%$ serta dari siklus I sebesar $66 \%$ ke siklus II sebesar $80 \%$. Jadi dari siklus I ke siklus II terjadi rata-rata peningkatan skor sebesar $17,50 \%$.

Berdasarkan hasil penelitian disarankan: (1) Kepada siswa hendaknya siswa mampu aktif bertanya ke guru jika memang ada hal yang kurang dimengerti dalam pembelajaran (2) Bagi guru dapat menerapkan metode inquiry based teaching untuk meningkatkan hasil belajar siswa; (3) Bagi pembaca dapat mengembangkan metode pembelajaran inquiry based taching dalam mata pelajaran lain dengan menerapkan konsep terbarukan yang tidak menghilangkan dasar dari metode pembelajaran inquiry based teaching.

\section{Daftar Rujukan}

Chaer, Abdul. 2009. Pengantar Semantik Bahasa Indonesia. Jakarta: Rineka Cipta.

Dep. Pend. Dan Kebudayaan, Kamus Besar Bahasa Indonesia, Balai Pustaka, Jakarta, 1990, h. 601.

Munirah. 2015 . Sistem Pendidikan Di Indonesia: Antara Keinginan Dan Realita . Jurnal Auladuna, Vol. 2 No. 2 Desember 2015: 233-245

Nurrohma, W. 2012. Peningkatan Motivasi Belajar Ipa Melalui Model Pembelajaran Ibl (Inquiry Based Learning) Pada Siswa Kelas IV SDN Tangkil 03 Sragen Tahun Pelajaran 2012/2013. (Skripsi). Surakarta: Universitas Muhammadiyah 
Nurkholis. 2013. Pendidikan Dalam Upaya Memajukan Teknologi . Jurnal Kependidikan, Vol. 1 No. 1 Nopember 2013

Giri Mas, Maskatno. 2015. Metode Pembelajaran Beserta Prosedurnya. Wonogiri. Tersedia pada : https://www.kompasiana.com/sukatno/5519f045a33311c71cb659a6/metodepembelajaran-beserta-prosedurnya-terutama-pemb-bahasa-ditulis-ulang-olehmaskatno-giri-mas-guru-sman-1-girimarto-wonogiri (diakses tanggal 15 Juni 2019)

Hudoyo, Herman. 1990. Strategi mengajar belajar BAHASA INGGRIS, Malang : IKIP Malang.

Littlewood, W. 1984. Foreign and Second Language Learning. London: Cambridge University Press.

Mardapi, Djemari. 2008. Teknik Penyusunan Instrumen Tes dan Non tes. Yogyakarta : Mitra Cendikia

Mc. Taggart, R dan Kemmis, S. 1990. The Action Research Planner. Melbourne. Deakin University.

Nunan, D. 2005. Task-Based Language Teaching. London: Cambridge University Press

Quirk, R. 1972. A Grammar of Contemporary English. London: Longman.

Richards, Jack C. \& Schmidt, Richard. 2010. Longman Dictionary of Language Teaching and Applied Linguistics. Great Britain : Pearson Education Limited.

Saminanto. 2010. PTK. Semarang: RaSAIL Media Group: hlm. 48

Shafique Ali Khan. 2005. Filsafat Pendidikan Al-Ghazali. Bandung: Pustaka Setia

Slameto. 1995. Belajar Dan Faktor-Faktor Yang Mempengaruhinya. Jakarta: Rineka Cipta

Sutrisno. 2016. Berbagai Pendekatan Dalam Pendidikan Nilai Dan Pendidikan Kewarganegaraan . Jurnal Dimensi Pendidikan dan Pembelajaran Vol.5 Januari 2016

Syaiful Bahri Djamarah. 2002. Psikologi Belajar. Jakarta: Rineka Cipta 